\section{Kastamonu Eğitim Dergisi Kastamonu Education Journal}

Ocak 2019 Cilt:27 Sayı:1

kefdergi.kastamonu.edu.tr
Başvuru Tarihi/Received: 05.04.2018

Kabul Tarihi/Accepted: 25.04.2018

DOI: $10.24106 /$ kefdergi.2960

\title{
Özel Gereksinimli Çocuğa Sahip Anne Babaların Yaşam Doyumlarının Öz- Anlayış ve Merhamet Düzeyleri Açısından İncelenmesi
}

\section{Investigation of Life Satisfaction of The Parents Who Have Children With Special Needs in Terms of Their Compassion and Self-Understanding Levels}

\section{Öz}

\author{
Selahattin AVŞAROĞLU1', Esen GÜLEŞ²
}

Bu araştırmada, özel gereksinimli çocuğa sahip anne babaların, yaşam doyumları-nın öz-anlayış ve merhamet düzeyleri açısından incelenmesi amaçlanmıştır. Araştırmanın ana değişkenleri olan öz-anlayış, merhamet ve yaşam doyumları tek tek ele alınmıştır. Verilerin anali-zinde aritmetik ortalama, ağırlıklı ortalama, $\mathrm{t}$ testi, $\mathrm{F}$ testi, Pearson korelasyon katsayısı ve Stepwise Regresyon analizi teknikleri kullanılmıştı. Araştırmanın grubunu, 2016 yılında Konya'da bulunan kaynaştırma, alt sınıf, eğitim uygulama okulu ve rehabilitasyon merkezine devam eden özel gereksinimli çocuğa sahip 188 anne ve 113 baba olmak üzere toplam 301 ebeveyn oluşturmuştur.

Araştırma bulgularına göre, özel gereksinimli çocuğa sahip anne babaların öz anlayışları, merhamet düzeyleri ve yaşam doyumları arasında anlamlı ilişkiler bulunmuştur. Anne-babaların merhamet düzeyi alt boyutlarında sevecenlik, umursamazlık, paylaşımların bilincinde olma, bağlantısızlık, ilişki kesme puanları, yaşam doyumuyla anlamlı düzeyde ilişkilidir. Merhamet ölçeğinin olumsuz boyutları olan umursamazlık, bağlantısızlık ve ilişki kesme boyutları yaşam doyumuyla ters yönlü bir ilişki göstermişken olumlu boyutları olan sevecenlik, paylaşımların bilincinde olmada fazla puanlar alan anne babaların ise yaşam doyumlarının daha yüksek olduğu bulunmuştur. Öz-anlayış ve merhamet düzeylerinin yaşam doyumu anlamlı düzeyde yordadığı saptanmıştr. Araşttrma bulgularına göre özel gereksinimli çocuğa sahip anne babaların yaşam doyumlarını artırıcı öz-anlayış ve merhametli tutumlarını artırıcı psikolojik danışma ve rehberlik hizmetleri verilebilir.

Anahtar Kelimeler: Merhamet, öz-anlayış, özel eğitim, özel gereksinimli çocuk, yaşam doyumu.

\section{Abstract}

In this research it is aimed to examine the life satisfaction of self-understanding and compassion levels of parents who have children with special needs. The main variables of the study were self-understanding, compassion and life satisfaction. Arithmetic mean, weighted mean, $\mathrm{t}$ test, $\mathrm{F}$ test, Pearson correlation coefficient and Stepwise regression analysis techniques were used in the analysis of the data. The group of the study comprised of 301 parents, including 188 mothers and 113 fathers, who have children with special needs attending the rehabilitation center, mainstream school, lower class and an educational practice school in Konya in 2016.

According to research findings, significant relationships were found between these parents' self-understanding, compassion levels and life satisfaction. Parental compassion level sub-dimensions are significantly associated with compassion, indifference, consciousness of sharing, disconnection, severity of relationship and life satisfaction. Negligence, disconnection and severance, which are the negative dimensions of compassion scale, have negative relationship with life satisfaction, while humaneness and parents with higher scores of sharing, which are the positive dimension of compassion scale, have higher life satisfaction levels. Another important finding is that levels of self-understanding and compassion predict life satisfaction at a meaningful level. According to research findings, psychological counseling and guidance services can be given to increase the self-understanding, compassionate attitudes and life satisfaction of parents who have children with special needs.

Keywords: Children with special need, compassion, life satisfaction, self-understanding, special education.

1. Necmettin Erbakan Üniversitesi/Kırgızistan Türkiye Manas Üniversitesi Eğitim Bilimleri Bölümü, Bişkek, Kırgızistan; https://orcid.org/0000-0002-0953-2922 2. Adaptasyon Özel Eğitim ve Rehabilitasyon Merkezi Konya, Türkiye; https://orcid.org/0000-0002-3990-4299

Atıf / Citation: Avşaroğlu, S., \& Güleş, E. (2019). Özel gereksinimli çocuğa sahip anne babaların yaşam doyumlarının öz-anlayış ve merhamet düzeyleri açısından incelenmesi. Kastamonu Education Journal, 27(1), 365-376. doi:10.24106/kefdergi.2960 


\section{Extended Abstract}

Purpose: Having a child with special needs means having a child, which brings with it cer-tain special difficulties regardless of the type of disability. These difficulties are: educational status, psychological issues, lifestyle, economic problems, social envi-ronment and family environment, child's disability status. In this process, there may be difficult feelings to endure, or there may be difficulties for parents to bear. These difficulties can affect the life satisfaction of the family. Life satisfaction expresses a state of being comfortable in terms of moral, happiness, etc., and means when posi-tive emotion dominates negative emotion in daily relationships. It is the emotional response or attitude of the person towards his work, leisure and other periods of his life. Therefore, it defines the person's positive evaluation of life as a complex of cognitive evaluations and general satisfaction. There are various concepts related to life satisfaction. One of them is the concept of self-understanding and compassion. The decrease or increase of the effect of these factors, which can be taken under two headings as internal and environmental factors, affects life satisfaction. One of the important factors affecting the life satisfaction of the person is the self-understanding which can be considered as a new concept in the psychology literatu-re. It is useful to know the level of self-understanding and compassion of parents who have children with special needs. Self-understanding can be described as understanding and taking care of himself, accepting adverse events as a part of mankind's life rather than criticizing himself in cases like suffering and failure; as well as holding it with a logical consciousness rather than standing on negative feelings and thoughts. It also implicates being open to his own sufferings, producing a desire to relieve his pain, curing him with compassion, and most importantly questioning his pain, inadequacy and failure as a part of gaining greater experience. Negative traits of people with high self-understanding scores appear to be low. On the contrary, people who do too much self-criticism are also known to have difficulty in relaxing themselves. Parents' compassionate attitudes are very important for children. The main peculiarity of compassion which distinguishes it from other concepts such as sympathy, empathy and altruism, is that how it embraces the desire for pain relief, the cognitive process of understanding the source of pain, and the behavioral process of being involved in compassionate actions. It is of great importance how parents' self-understanding forms provide a positive contribution to themselves and their children, and on the other hand, how a compassionate attitude contributes positively to care and other kinds of support. It can be said that, factually, compassionate and self-understanding individuals' attitude towards themselves and their surroundings is more positive. The research was designed in accordance with this purpose.

Method: In this study, a general screening model, one of the descriptive research methods, was used. On the basis of this model, the way how independent variable affected the dependent variable was investigated. The research group of this study comprises 301 mothers and fathers who have a child with special needs attending the rehabilitation center, the lower class, the school of education and practice primarily in the Konya province. The Life Satisfaction Scale, which was developed by Diener et al. (1985) and adapted into Turkish by Köker (1991) was used in the research. The self-understanding scale, which was developed by Neff (2003) and Turkish adaptation of which was made by Deniz, Kesici and Sumer (2008) was used, as well. The compassion scale implemented by Pommier (2011), developed by the Mediterranean and Sea (2016), was used. Parametric statistical techniques have been used since the data obtained on scales applied to parents of children with special needs show a normal distribution. For this purpose, arithmetic mean, weighted mean, independent sample $t$ test, $F$ test, Pearson correlation coefficient and Stepwise regression analysis techniques were used in the analysis of the data.

Findings :In this study, it was found that the life satisfaction of parents who have children with special needs is high. In terms of gender, the average life expectancy of the fathers was found to be higher than the average of the groups. It was determined that the parents' self-understanding was moderate and there was no significant difference between the sexes. Parents were found to have a very high level of compassion in the dimension of "affection",one of the sub-dimensions of compassion scale. Parents were found to have high levels of compassion in the dimensions of "positive awareness" and "conscious awareness," which appear to be other positive dimensions of the poverty scale. However, in the three negative dimensions of the compassion scale, it was seen that parents had a low average of "negligence, disconnection and severance". There was a significant difference in terms of gender in the subdimension of "affection". This difference was in favor of their mothers and mothers were found to be more compassionate in comparison with their fathers. When the parents' scores on the pity scale were examined, they showed that compassion, irreverence, the consciousness of sharing, disconnection, dismissal, and total scores of scale had meaningful relationships with life satisfaction. In terms of the correlation coefficient, the dimensions of negligence, disconnection and severance showed an inverse relationship with life satisfaction. Parents who scored high on these negative dimensions of the compassion scale had low scores on life satisfaction. On the other hand, parents who had high scores on the compassion, which is the positive dimension of the mercy scale, had shown higher life satisfaction level. Both self-understanding and compassionate attitudes of parents with special needs children are crucial to their life satisfaction. This research is important in terms of the finding that parents' self-understanding and compassionate attitudes toward children with special needs positively effect their life satisfaction. Psychological counseling and guidance services that increase the level of self-understanding and compassion can be provided, as well as having various factors that increase life satisfaction of these families. In the light of findings of this research, psychological counselors can test educational programs such as empowering self-understanding and earning a compassionate attitude by conducting empirical studies. 


\section{Giriş}

Bir toplum için aile kurumu çok mühimdir ve toplumun nüvesini oluşturmaktadır. Aile, bir çocuk için daha da önemlidir. Aile çocuğun büyümesinde, gelişim göstermesinde, bilgilenmesinde ve toplum içinde çeşitli rol ve sorumluluklar üst-lenmesinde sorumludur. Fakat çocuğun normalden farklı doğması veya yaşı ilerle-dikçe yaşıtlarından farklıık göstermesi bu güzel hislerin yerini olumsuz hislerin almasına neden olabilmektedir (Eripek, 1996) ve ailenin sorumluluğunu daha da arttırmaktadır. Özel gereksinimli bir çocuk sahibi olmak demek, engel türü ne olursa olsun birtakım özel güçlükleri de beraberinde getirmektedir (Mutluer, 1997; Akıncı ve Darıca, 2000). Bu güçlükler; eğitim durumu, psikolojik, yaşam tarzı, ekonomik, sosyal çevre ve aile çevresi ile ilişkiler, çocuğun engel durumu olarak gruplandırılabilir (Cavkaytar, 2010; Özşenol, vd., 2003).

Bu süreçte katlanması zor duygudurumları yaşanabilir. Zaman zaman engelli çocuk, özellikle annenin kişisel başarısı veya başarısızlığı olarak değerlendirildiği; normal gelişim göstermeyen bir çocuk başarılamayan bir çocuk olarak algılandığı için anne, çevresi tarafindan suçlu görülebilmektedir. Babanın özel gereksinimli bir çocuk sahibi olmaya karşı tepkileri de direk annenin duygularını etkilemekte, anneyi umutsuz, kaygı (Avşaroğlu ve Gilik, 2017), endişe hisleri ve çaresizlikleri ile karşı karşıya getirerek sağlıksız bir süreç görülmektedir (Eripek, 2009; Varol, 2010; Avşaroğlu, 2012). Bununla birlikte yine de özel gereksinimli çocukların sorumluluk ve günlük bakımlarını annelerin daha çok üstlendikleri görülmektedir (Marcenko ve Meyers 1991). Bu yüzden ailelerin duygusal problemlerinde ve uyumlarında kullan-dıkları, başa çıkma yöntemleri önemlidir (Knafl ve Zoeller, 2000).

Özel gereksinimli çocuğun sağlık durumu ve davranışları üzerinde annelerin ba-balardan daha önemli oldukları tespit edilmiştir (Heller, Hsieh and Rowitz, 1997). Özel gereksinimli çocuğu olan annelerin çocuklarının bakım zorluğunun, depresyonu tetiklediği ve (Gowen, Martın, Goldman and Appelbaum, 1989) çocuklarının durumu ile ilgili annelerin babalardan daha fazla endişelendikleri görülmektedir (Baykoç, Bay-han ve Artan, 2000). Bu durumda ise annelere verilen sosyal destekten babalara göre daha fazla etkilenip yararlandıkları saptanmıştır (Krauss, 1993). Bunun yanı sıra tek yaşayan annelerin tek yaşamayan annelerden daha çok stres yaşadıkları da göz ardı edilemeyecek bir durumdur (Beckman, 1983) Bu süreç ve bakım hizmetlerinden dolayı şüphesiz özel gereksinimli çocuğa sahip ailelerin yaşam doyumları araştırma konusu olmaktadır. Yaşam doyumunu etkileyen çoklu faktör içerisinde bireyin kişisel özellikleri ve içsel faktörler hakkında çalışmaların yapılması ve anne babalara katkılar sağlanması açısandan önemlidir.

Yaşam doyumu; kişinin iş durumu, boş vakit ve diğer zaman dilimlerindeki yaşamına gösterdiği duygusal tepki veya tutumudur. Yaşam doyumu ile yaş, cinsiyet, çalışma ve iş koşulları, eğitim seviyesi, dil, ırk, eğitim düzeyi, evlilik ve aile yaşamı, toplumsal yaşam, kişilik özellikleri, biyolojik etkenler gibi çok fazla değişken ilişkili (Köker, 1991) olabilmektedir. Yaşam doyumu; moral, mutluluk gibi değişik açılardan iyilik halini ifade eder ve günlük ilişkiler içinde pozitif duygunun negatif duy-guya hakim olmasıdır (Avşaroğlu, vd., 2005). Bireyin kendisine yüklediği kriterler ve yaşam koşullarını algılayışı arasındaki karşılaştırması ve yaşamı hakkında değer biçmesini içermektedir (Deniz ve Yılmaz, 2006; Selçukoğlu, 2001; Tuzgöl, 2011). Yaşam doyumu ile ilgili önemli çalışmalar yapan Diener (1996) ise yaşam doyumunu, kişinin hayata ilişkin olumlu değerlendirmeleri, bilişsel değerlendirmeleri ve genel memnuniyetinin toplamı olarak tanımlar. Vara'ya (1999) gore yaşam doyumu; mutluluk, moral gibi açılardan iyilik durumunu ve yaşam içerisinde pozitif duygunun negatif duyguya hâkim olmasıdır. Bireyin yaşam kalite-sinin artması, kişilerarası ilişkilerde olumlu sonuçlar alması ve yaşama dönük pozitif algısının çoğalması olarak tanımlanabilir. (Akandere, vd., 2009; Tümkaya, vd., 2008). Bunun yanı kişilerin, çeşitli gruplar içindeki yaşamı genel olarak kişinin yaşama ilişkin algılamasına ve doyumuna etki edebilmektedir. Akandere vd., (2009) zihinsel, fiziksel ve zihinsel-fiziksel engelli çocuğa sahip olan anne-babaların umutsuzluk ve yaşam doyum düzeyleri arasında anlamlı bir ilişki olduğunu vurgulamıştır. Tuncer (2017) yapmış olduğu araştırmasında sosyal anksiyete düzeylerinin yaşam doyumunu azalttı̆ıını vurgulamıştır. Bu araştırma bulgularına göre kişinin yaşam doyumu çok fazla faktörden etkilenmektedir (Tuncer, 2017). İçsel ve çevresel faktör olarak iki başlık altına alınabilecek bu faktörlerin etkisinin azalması ya da artması yaşam doyumunu etkilemektedir. Kişinin yaşam doyumunu etkileyen önemli faktörlerden biri de psikoloji literatüründe henüz yeni sayılabilecek olan öz-anlayış düzeyidir. Bu çalışmanın ana değişkenlerinden biri öz-anlayış olduğu için bu kavramı literatür eşliğinde tanımlamakta fayda vardır.

Öz-anlayış, kişinin acı ve başarısızlık durumlarında kendini eleştirmekten daha çok kendisine özen gösterme ve anlayışlı davranma, yaşadığı olumsuz olayların insanlığın yaşamının bir bölümü olarak görme, negatif duygu ve düşüncelerin üzerinde çokça durmak yerine mantıklı bir bilinçle tutma olarak açıklanabilir (Neff, 2003 a). Kişinin kendi acısına açık olması, acısını dindirme isteği üretmesi, şefkatle onu iyileştirmesidir. En önemlisi de daha büyük bir tecrübe kazanmanın bir parçası olarak kendi acı, yetersizlik ve başarısızlığını sorgulamadan anlamayı içermektedir. Deniz, Şahin ve Sümer (2008), öz-anlayış kavramını; kendilerine şefkat, kendilerine ortak paydaşım, kendine düşüncelilik şeklinde daha sistemli hal alması için üç ana öğeye ayırmışlardır. Kendilerine şefkat gösteren kişiler, kendisine yönelik sert bir öz-eleştiri ve 
sorgulamada bulunmazlar (Neff, 2003a; Neff, 2003b; Neff, vd., 2005). Kişinin kendini sert sorgulaması, kişinin kendisini arka plana atma ve diğer kişilerle daha zayıf bağlantı kurma duygusundan dolayı olabilmektedir. Öz-anlayışı yüksek insanlarda negatif özellikler görülmemekte, tersine öz-eleştiriyi çok fazla yapan insanlar kendilerini rahatlatmakta zorluk yaşamaktadırlar (Gilbert ve Irons, 2005; Gilbert ve Procter, 2009; Sarıcaoğlu, 2015).

Kişinin negatif hislerden uzaklaşabilmesi için belli bir miktar olumlu düşünceli olma hissine sahip olması gerekmektedir. Buna rağmen, düşünceli olmak diğer bile-şenlere daha doğrudan bir katkı sağlayabilmektedir. Öncelikli olarak, yargılayıcılık içermeyen bir düşünce kendini anlama oranını arttırır ve eleştiriyi azaltır (Neff, 2003a; 2003b). Kendilerine ortak paydaşım gösteren kişiler, kendisi ile ilgili problemlerde izolasyon ve ayrım yapmaktan ziyade, problemleri yaşamın getirdiği ve sadece kendilerinin başına gelmediklerini ve başka insanların da bunun gibi sorunla-rı yaşayabileceklerine ilişkin deneyim kazanma aracı olarak düşünmektedirler (Neff, 2003a). Ortak paydaşım, kişinin içinde bulunduğu sıkınt ve acı veren negatif hislerden kaçınmak yerine bu negatif hisleri pozitif biçimde ve kendi lehine düzenlemesidir. Ortak paydaşım yapabilen insanlar, hem kendilerine hem de diğer bireylere hoşgörü gösterirler. Çünkü bu ortak paydaşım evrensel değerlerin özünde vardır (Şahin vd., 2008). Kişiler tam bir öz-anlayış hali için düşüncelilik perspektifi benimsemelidirler. Yani kendine acı veren duygulardan kaçmamalı, aynı şekilde aşırı belirlemeci bir tutumdan kaçınmalı, belli bir oranda "zihinsel boşluk" oluşturmalıdırlar ve kendilerini ortak paydaşım sınırları içinde deneyimlemelidirler (Neff, 2003a). Kişiler bazen keder, acı, başarısızlık ve tükenmişlik gibi negatif duyguları yaşayabilirler. Böyle durumlarda öz-anlayış geliştirilerek yaşamdaki olumsuz duygulardan kurtulma imkanı sağlanabilir. Anlayış, öz-anlayış kavramının temelindedir. Çünkü anlayış, başka bireylerin üzüntülerini göz ardı etmemeyi, diğerlerine şefkat ile yaklaşmayı, karşımızdaki bireyleri yargılamadan anlayabilmeyi içerir (Güleş ve Avşaroğlu, 2017). O halde kişide öz-anlayış geliştiği zaman kendisi ile ilgili pozitif düşünceler gelişmekte ve negatif düşüncelerin etkisi hafifleyerek, karşılaşth̆̆ olumsuz durumlardan kendisine deneyim elde etmektedir (Şahin vd., 2008). Bandura (1997) öz-yeterlik inançları yüksek olan bireylerin, mücadele etmek zorunda oldukları ve yeni karşılaştıkları yaşantılardan kaçmadıklarını ve eylemlerini başarılı bir biçimde bitirebilmek için oldukça kararlı olduklarını vurgulamaktadır. Öz-anlayış kişilerin, yaşamlarında karşılaştıkları güçlüklerle baş etmesi açısından çok önemlidir. Hem bu zorlantılarla baş etmesi açısından hem de ruhsal anlamda sağlıksız bir evreye geçmeden varlığını korumak gerekmektedir. Kişiler, hem anne-baba rollerini en sağlıklı şekilde sergilemeli hem de gündelik yaşamlarında koşullarını olumlu yöne çekebilmenin çabasını vermelidirler.

Özel gereksinimli çocuk için Öz-anlayışlı anne-baba tutumu ne kadar önemli ise anne babanın merhametli bir tutum göstermesi de o kadar önemlidir. Genel anlamda merhamet, içsel bir değer ve bir duygudur. Duygular veya değerler boyun eğilecek birer kural değildir. Kant'a göre merhamette hissetmek bir zorunluluk değil içimizden gelen manevi bir duygudur ve bu duygu geliştirilebilir. Rousseau ise, merhameti içimizden gelen "doğal duygu" olarak tanımlamaktadır. Aslında merhamet sadece insanlara değil, tüm canlılara karşı oluşturulan bir duygudur. Bireylerin merhamet duygusu ancak çevresindeki kişilerin çektikleri acı ve sıkıntıları fark ettiklerinde harekete geçebilir (Schopenhauer, 2007). Merhamet, kişinin diğerlerinin sıkıntılı durumlarında gösterdiği farkındalığın yanı sıra sıkıntıyı giderme çabasını içeren yardımseverlik tutumudur (Güleş ve Avşaroğlu, 2015). Gilbert'e göre (2005) merhamet; başkasının acısını ortadan kaldırma isteğini, acının kaynağını anlamaya yönelik bilişsel süreç ve merhametli eylemlerde bulunmak ile ilgili davranışsal süreci içerisinde barındırmaktadır. Dolayısı ile merhamet; duygu, düşünce, güdü ve davranışın birleşimi ile oluşmaktadır. Merhamet, insanların sıkıntılarına empati duyma, acıma ve şefkat gösterme, ondan kurtulması için harekete geçme işlemidir. Sadece histe ve düşüncede kalırsa merhamet olmaktan çıkar ve tipik bir acıma hissine döner. Merhametin ayrıcı özelliğinde sıkıntıyı gidermeye dönük hareket etme vardır. Hökelekli, (2007), merhameti yalnızca başkalarının başına gelen kötü durumların kendi başımıza gelmesinden korktuğumuz için hissettiğimiz bir duygu değil, gelemeyecek olan durumlarda da oluşan bir duygu olarak tanımlamıştır. Duygular, davranışlarımızın temelidir ve temel tetikleyici faktörleridir. Bununla birlikte merhametin kökleri duygulardan beslense de davranışa dönüştürülmesi açısından çeşitli öğrenmelere ihtiyaç duyar. Bunun için çocuk ve yetişkin eğitimlerinde merhametli tutumların geliştirilmesi aynı zamanda öğrenme yolu ile de sağlanabilmektedir ve merhametli tutum insanlara yük değildir (Hergül, 2010). Tam tersi ihtiyacı olanın, en olunması gerektiği anda yanında olunması işidir. Bakıma muhtaç çocuk, gereksinimli çocuk, düşkün bir insan, bir yaşı, bir sokak hayvanı gibi hemen hemen herkesi ilgilendiren bir yaşam ortaklığıdır.

Psikoloji literatüründe ya da psikolojik danışma ve rehberlik hizmetlerinde mer-hamet (Sayar, 2011) yıllarca ihmal edilmiş; prososyal davranış, yakınlık davranışı, alturizm ve duygudaşlık gibi benzer kavramların altında incelenmiştir (Gilbert, 2005). Empati gibi kavramlar adı altında çalışıldığının düşünülmesi, karmaşık bir yapıya sahip olması ve ölçümünün zor olması gibi sebeplerle merhamet kavramının psikolojide geç yer bulduğu söylenebilir (Braun, 1992). Bu yüzden insan ilişkilerinde ve karakter ve kişilik gelişiminde diğer kavramların gölgesinde kalmıştır. Fakat son zamanlarda psikolojideki patolojilere odaklanmak yerine, psikolojik güçlülüğe ve iyi oluşa odaklanmaya kayan yeni yönelimler bu konudaki çalışmalara hız kazandırmıştır (Seligman, Steen, Park ve Peterson, 2005). Merhamet’i; sempati, empati ve al-

| Kastamonu Eğitim Dergisi, 27(1), 2019| 
turizm gibi benzer diğer kavramlardan ayıran temel özellik onun acıyı giderme isteğini, acının kaynağını anlamayla ilgili bilişsel süreci ve merhametli eylemlerde bulunmakla ilgili davranışsal süreci bir arada içerisinde barındırıyor olmasıdır. Yani merhamet; güdü, duygu, düşünce ve davranışın birleşimi ile oluşmaktadır (Gilbert, 2005). Cassel (2002), merhametin oluşma sürecini üç basamakta özetlemiştir. Buna göre kişi, diğerinin sıkıntısına acısına şahit olmalı, acı veren durumu birey kendine kasten yapmış olmamalı ve acı veren durum bireye kendisini karşısındakinin yerine koymasına imkan verecek şekilde tanıdık gelmelidir. Underwood'a göre (2002) kişinin kendi duygularının farkında olması, dünyada kendisinden daha büyük bir şeyi temsil ettiğine dair inancı, bireyi merhametli davranmaya sevk ettiğini vurgulamıştı.

\section{Araştırmanın Amacı}

Araştırmanın ana değişkenleri olan yaşam doyumu, öz-anlayış ve merhamet kavramları literature ışığında açıklanmaya çalışılmıştr. Araştırmanın veri toplama sürecinde hedef kitle, özel gereksinimli çocuğa sahip aileler olduğu için özel gereksinimli çocukların gelişimleri, bakımları, onlarla kurulması gereken özel iletişim yöntemleri, yaşıtlarına göre gelişimsel yetersizlikleri gibi istenmeyen durumlardan dolayı bu ailelerin yaşam doyumlarının bilinmesi önem arz etmektedir. Bununla birlikte onların öz-anlayış biçimleri kendilerine ve çocuklarına karşı olumlu bir katkının sağlayıp sağlamadığı, diğer taraftan merhametli bir tutumun bakım verme ve diğer desteklere olumlu yönde katkı sağlıyor mu? gibi soruların cevapları önemlidir. Olgusal olarak merhametli ve öz-anlayışlı bireylerin kendine ve çevresine daha olumlu yaklaştkları söylenebilir. Bu amaç doğrultusunda aşağıda alt amaçlar geliştirilmiştir.

\section{Araştırmanın Alt Amaçları}

1. Özel gereksinimli çocuğa sahip anne ve babaların yaşam doyumları puan ortalamaları ne düzeydedir?

2. Özel gereksinimli çocuğa sahip anne ve babaların öz-anlayış puan ortala-maları ne düzeydedir?

3. Özel gereksinimli çocuğa sahip anne ve babaların merhamet duyguları puan ortalamaları ne düzeydedir?

4. Özel gereksinimli çocuğa sahip anne ve babaların öz-anlayış, merhamet düzeyi ve yaşam doyumları puan ortalamaları arasında anlamlı bir ilişki var mıdır?

5. Özel gereksinimli çocuğa sahip anne ve babaların öz-anlayış ve merhamet puanları yaşam doyumlarını anlamlı düzeyde yordamakta mıdır?

\section{Yöntem}

Bu araştrmada betimsel araştırma yöntemlerinden genel tarama modeli kulla-nılmıştır. Bu model ile bağımsız değişkenin bağımlı değişkeni nasıl etkilediği araşt-rılmıştr. Genel tarama modeli çok sayıda elemandan oluşan bir evrende, evren hakkında genel bir yargıya ulaşmak için, evrenin tamamını veya ondan alınacak bir grup, örnek veya örneklem üzerinde yapılan tarama düzenlemeleridir (Karasar, 1994). Bu çalışmada özel gereksinimli çocuğa sahip anne ve babaların öz-anlayış, merhamet ve yaşam doyumları bir örneklem üzerinde bazı değişkenler açısından betimlenip evrene genellenmeye çalışılmıştır.

\section{Araştırma Grubu}

Bu çalışmanın araştırma grubunu, Konya il ve ilçelerinde bulunan kaynaştırma kararı alan, alt sınıf, eğitim uygulama okulu, rehabilitasyon merkezine devam eden özel gereksinimli çocuğa sahip 188 anne ve 113 baba olmak üzeretoplam 301 ebeveyn oluşturmaktadır. Araştırma grubu, küme örnekleme yoluyla özel gereksinimli çocukların eğitimlerini sürdürdükleri 6 kurumdan oluşturulmuştur.

\section{Veri Toplama Araçları}

\section{Yaşam Doyumu Ölçeği}

Yaşam doyumu ölçeği Diener, Emmons, Larsen ve Griffin (1985) tarafindan ge-liştirilmiştir. Köker (1991) tarafindan Türkçe'ye uyarlanmıştr. Ölçek 5 maddeden oluşmaktadır. Ölçek 7'li likert tipine sahiptir ve "kesinlikle katılmıyorum" (1) ile "kesinlikle kathlıyorum" (7) arasında değişmektedir. Ölçeğin orijinal halinin puan-lanmasında yüksek ve düşük yaşam doyumuna sahip olan bireyleri belirlemek için grubun aritmetik ortalaması kullanılmaktadır. Aritmetik ortalamanın üzerinde olan bireylerin yaşam doyumunun yüksek, aritmetik ortalamanın altında olan bireylerin ise yaşam doyumunun düşük olduğu belirtilmiştir. Köker (1991) ölçeğin üç hafta arayla uygulanan test tekrar test tutarlılık katsayısının 0.85 olduğunu belirlemiştir (Karatekin, 2013).

Özel gereksinimli çocuğa sahip aile örnekleminde gerçekleştirilen uygulamalar sonucu yaşam doyum ölçeğinin güvenirlik katsayısı 0,84 olarak bulunmuştur. Bu sonuç daha önce bu ölçeğin uygulandığı farklı araştrrmalardaki güvenirlik katsayıları ile tutarlıdır. Tek boyutlu olan ölçeğin her bir maddesi üzerinde gerçekleştirilen Item-Toplam analizleri ise aşağıdadır. 
Tablo 1. Yaşam Doyumu Madde Test Korelasyonu

\begin{tabular}{lc}
\hline & Item-Toplam Korelasyon \\
\hline Soru 1 & .617 \\
Soru 2 & .627 \\
Soru 3 & .735 \\
Soru 4 & .679 \\
Soru 5 & .594 \\
\hline
\end{tabular}

Bu verilere göre özel gereksinimli çocukların anne ve babalarına uygulanan Yaşam Doyum Ölçeği gerek bütün olarak gerekse her bir maddesi ayrıcı ve tutarlı bir ölçümü sağlamıştır.

\section{Öz-Anlayış Ölçeği}

Öz-anlayış ölçeği (SCS; Self-CompassionScale) Neff (2003) tarafindan geliştirilmiştir. Ölçeğin Türkçe uyarlaması, geçerlik ve güvenirlik çalışması Deniz, Kesici ve Sümer (2008) tarafindan yapılmıştı. Öz-anlayış Ölçeği (SCS; Self-CompassionScale) katlımcıların alt ölçeklerdeki değerlere ve oradan da genel değerlere ulaşmayı amaçlamıştır. Ölçek, Öz-anlayışı oluşturan üç ana bileşenden oluşturulmuştur: kendine şefkat, kendine paydaşım ve kendine düşüncelilik. Birbiriyle ilişkili bu üç ana bileşenin asıl hedefi öz-anlayışı ölçmek olarak belirlenmiştir (Neff, 2003). Ölçek, 5'li likert tipidir. "Hemen hemen hiçbir zaman= 1" ve "Hemen hemen her zaman= 5" arasında olmak üzere değişmektedir.

Öz-anlayış Ölçeği 26 maddedir. Öz-nezaket, öz-yargılama, ortak insanlık, izolasyon, bilinçlilik, aşırı-özdeşleşme olmak üzere 6 alt ölçekten oluşmaktadır. Ölçeğin iç tutarlııık katsayısı (Cronbach Alpha) bütünü için .92, alt ölçekler için de sırayla $.78, .77, .80, .79, .75, .81$ ve test-tekrar test güvenirliği ölçeğin bütünü için .93 , alt ölçekler için de sırayla $88, .88$, $.80, .85, .85, .88$ olarak bulunmuştur (Neff, 2003; Akt; Deniz, vd., 2008).

Araştrrmacılar, Türkçe Öz-Anlayış Ölçeği (ÖAÖ)'nin orijinalinden farklı olarak ölçeğin tek boyutlu bir yapı gösterdiğini belirtmişlerdir. 26 madde için madde toplam korelasyonu, .029 ile .646 arasında değişmektedir. Bundan dolayı madde toplam korelasyonu .30'un altında olan ölçekten çıkartılmıştır. Madde toplam korelasyonunda $.30^{\prime}$ altında olan 1 . ve 22. maddeler olmak üzere iki maddeyi, ölçekten çıkartarak toplam 24 maddelik bir ölçek elde etmişlerdir. Ölçeğin güvenirliği belirlemek için yapılan madde analizine bağı olarak hesaplanan Cronbach Alpha iç tutarlıık katsayısı .89'dur. Ayrıca iç tutarlılık katsayısı .89 ve test-tekrar test korelasyon .83 olarak hesaplamışlardır. Öz-anlayış Ölçeğinin ölçütbağıntılı geçerliğinde ise, SCS ile RSES arasında $r=.62$; SWLS arasında $r=.45$; pozitif duygu arasında $r=.41$ ve negatif duygu arasında $r=-.48$ düzeyinde ilişkiler saptanmıştir (Deniz, vd., 2008).

Bu çalışmada, araştırmacılar tarafindan gerçekleştirilen güvenirlik ve geçerlik analizlerinde Öz-anlayış Ölçeğinin Cronbach Alfa katsayısı 0.89 bulunmuştur. Bu değer ölçeğin araştırma örneklemi açısından güvenirliğinin oldukça yüksek olduğunu göstermektedir. Tek boyutlu olan ölçeğin madde test korelasyonları aşağıda verilmiştir.

Tablo 2. Öz-Anlayış Madde Test Korelasyonu

\begin{tabular}{|c|c|c|c|c|c|}
\hline Maddeler & $\begin{array}{c}\text { Item-Test } \\
\text { Korelasyon }\end{array}$ & Maddeler & $\begin{array}{l}\text { Item-Test } \\
\text { Korelasyon }\end{array}$ & Maddeler & $\begin{array}{c}\text { Item-Test } \\
\text { Korelasyon }\end{array}$ \\
\hline s1 & .457 & s9 & .309 & s17 & .407 \\
\hline s2 & .338 & s10 & .451 & s18 & .609 \\
\hline s3 & .473 & s11 & .448 & s19 & .528 \\
\hline s4 & .474 & s12 & .526 & s20 & .414 \\
\hline s5 & .452 & s13 & .502 & s21 & .470 \\
\hline s6 & .363 & s14 & .423 & s22 & .560 \\
\hline s7 & .533 & s15 & .459 & s23 & .585 \\
\hline s8 & .527 & s16 & .440 & s24 & .508 \\
\hline
\end{tabular}

Analizlere göre her bir maddenin madde-test korelasyonu 0.30'un üzerindedir. Bu bulgulara göre Öz-anlayış ölçeğinin her bir maddesi testin bütünüyle tutarlı ve aynı yönde özellikleri ayırııı bir şekilde ölçmektedir.

\section{Merhamet Ölçeği}

Orijinali Pommier (2011) tarafindan geliştirilen Türkçe' ye uyarlaması Akdeniz ve Deniz (2016) tarafindan gerçekleştirilen Merhamet Ölçeği Likert formunda 24 sorudan oluşmaktadır. Doğrulayıc faktör analizi ile gerçekleştirilen yapı 
geçerliği testlerinde ölçeğin 6 boyuttan oluştuğu görülmüştür. Bu boyutlar sevecenlik, umursamazlık, paylaşımların bilincinde olma, bağlantısızlık, bilinçli farkındalık, ilişki kesme'dir. Umursamazlık, bağlantısızık, ilişki kesme alt boyutları tersten puanlanmaktadır. Diğer olumlu merhamet özelliklerini ölçen boyutlar ise doğrudan olumlu cevap seçeneği 5 , olumsuz cevap seçeneği 1 olacak şekilde puanlanmaktadır. Alt boyutları ayrı ayrı puanlamamız gerektiği durumlarda tersten puanlama yapılmayacaktır. Örneğin umursamazlık alt boyutunu tek başına ölçmek istediğimizde tersten puanlama yapmamamız gerekir. Toplam merhamet puanı için tersten puanlama yapılan alt boyutları puanladıktan sonra tüm alt boyutların toplamı alınacaktır.

Akdeniz ve Deniz (2016) tarafindan gerçekleştirilen güvenirlik analizlerinde ölçeğin alt boyutlarının Cronbach Alfa güvenirliği 0,60 ile 0,75 arasında değişmektedir. Bu çalışma için gerçekleştirilen iç tutarlılık analizlerinde testin her bir alt boyutu ve bütünü için güvenirlik katsayıları hesaplanmıştır. Cronbach Alfa analizlerine göre Sevecenlik alt ölçeği için .80 , umursamazlık alt ölçeğinde .65 , paylaşımların bilincinde olma .65 , bağlantısızlık alt ölçeğinde .66 , bilinçli farkındalık alt ölçeğinde .71 , ilişki kesme alt ölçeğinde .70 ve ölçeğin bütününde ise .78 güvenirlik katsayıları hesaplanmıştır. Literatürde likert tipi ölçeklere ilişkin güvenirlik çalışmalarında 0,60 ile 0,70 düzeyindeki katsayıların yeterli olduğu ileri sürülmektedir. Bu çalışmanın örneklemine uygulanan merhamet ölçeğinin bütünü ve alt boyutlarından elde edilen güvenirlik katsayılarının yeterli ve yüksek olduğu söylenebilir.

\section{Verilerin Analizi}

Bu araştırma, ilişkisel tarama modeli ile desenlenmiştir. Tarama modelleri, geçmişte ya da halen var olan bir durumu var olduğu şekliyle betimlemeyi amaçlayan araştırma yaklaşımlarıdır. Bu modelde önemli olan, var olanı değiştirmeye kalkmadan gözlemleyebilmektir (Karasar, 1994) iliş̧kisel tarama modeli ise, iki ya da daha çok sayıdaki değişken arasında birlikte değişim varlığını ve/veya derecesini belirlemeyi amaçlayan araşttrma modelleridir (Karasar, 1994). Özel gereksinimli çocukların anne babalarına uygulanan ölçeklerde elde edilen veriler normal dağılım gösterdiği için parametrik istatistik teknikleri kullanılmıştır. Bu amaçla verilerin analizinde aritmetik ortalama, ağırlıklı ortalama, bağımsız örneklem $\mathrm{t}$ testi, $\mathrm{F}$ testi, Pearson korelasyon katsayısı ve Stepwise Regresyon analizi teknikleri kullanılmıştır

\section{Bulgular}

Tablo 3. Özel Gereksinimli Çocuğa Sahip Anne ve Babaların Yaşam Doyum Düzeyleri

\begin{tabular}{lcccc}
\hline & $\bar{X}$ & S.S & Soru Sayısı & A ̆g. Ort. \\
\hline Yaşam Doyum & 22.07 & 6.624 & 5 & 4.414 \\
\hline
\end{tabular}

Tablo 3'e göre araştırma örnekleminin öz-anlayış ölçeği puan ortalaması 22,07'dir. Ağılıklı ortalama değeri ise 4,41'dir. Bu bulgu anne ve babaların yaşam doyumlarının yüksek düzeyde olduğunu göstermektedir.

Tablo 4. Özel Gereksinimli Çocuğa Sahip Anne ve Babaların Yaşam Doyumlarının Karşılaştırılması

\begin{tabular}{llccccc}
\hline Ebeveyn & & $\mathrm{n}$ & $\bar{X}$ & $\mathrm{s.s}$ & $\mathrm{t}$ & $\mathrm{p}$ \\
\hline \multirow{2}{*}{ Yaşam Doyum } & 1 (Anne) & 188 & 21.39 & 6.45 & -2.31 & .021 \\
& 2 (Baba) & 113 & 23.20 & 6.79 & & \\
\hline
\end{tabular}

Tablo 4'e göre ebeveynlerin puanları arasında 2.31 t değeri hesaplandığı gözlemlenmektedir. Bu bulguya göre iki grup arasında anlamlı bir fark söz konusudur. Grupların ortalamalarına bakıldığında babaların yaşam doyumlarının annelerden daha yüksek düzeyde olduğu görülmüştür.

Tablo 5. Özel Gereksinimli Çocuğa Sahip Anne ve Babaların Öz-Anlayış Düzeyleri

\begin{tabular}{lcccc}
\hline & $\bar{X}$ & s.s & Soru Sayısı & Ağ. Ort. \\
\hline Öz-Anlayış & 83.14 & 15.601 & 24 & 3.464 \\
\hline
\end{tabular}

Tablo 5 incelendiğinde, araştırma örnekleminin Öz-anlayış Ölçeği puan ortalaması 83.14'tür. Ağırlıklı ortalama değeri ise 3.46'dır. Bu bulgu anne ve babaların öz anlayışlarının orta düzeyde olduğunu göstermektedir. 
Tablo 6. Özel Gereksinimli Çocuğa Sahip Anne ve Babaların Öz-Anlayışlarının Karşılaştırılması

\begin{tabular}{llccccc}
\hline & & $\mathrm{n}$ & $\bar{X}$ & $\mathrm{~s} . \mathrm{s}$ & $\mathrm{t}$ & $\mathrm{p}$ \\
\hline \multirow{2}{*}{ Öz-Anlayış } & 1 (Anne) & 188 & 82.62 & 15.03 & -.746 & .456 \\
& 2 (Baba) & 113 & 84.01 & 16.54 & & \\
\hline
\end{tabular}

Tablo 6 incelendiğinde, ebeveynlerin öz-anlayış puan ortalamaları arasında 0.746 t değeri hesaplandığı görülmektedir. Bu bulguya göre anne babaların öz-anlayışları arasında 0.05 manidarlık düzeyinde anlamlı bir farkın olmadığı görülmektedir.

Tablo 7. Özel Gereksinimli Çocuğa Sahip Anne-Babaların Merhamet Düzeyleri

\begin{tabular}{lcccc}
\hline & $\bar{X}$ & S.S & Soru Sayısı & A . Ort. \\
\hline Sevecenlik & 17.17 & 3.070 & 4 & 4.292 \\
Umursamazlık & 8.10 & 3.172 & 4 & 2.024 \\
Paylaşımların Bilincinde Olma & 16.14 & 2.792 & 4 & 4.035 \\
Bağlantısızlık & 8.61 & 3.125 & 4 & 2.154 \\
Bilinçli Farkındalık & 16.43 & 2.846 & 4 & 4.106 \\
İlişki Kesme & 8.23 & 3.174 & 4 & 2.058 \\
Merhamet Toplam P & 96.79 & 13.405 & 24 & 4.033 \\
\hline
\end{tabular}

Tablo 7'ye göre, ebeveynlerin sevecenlik boyutunda yüksek düzeyde merhamet duygusuna sahip oldukları görülmüştür.

Tablo 8. Özel Gereksinimli Çocuğa Sahip Anne ve Babaların Merhamet Puanlarının Karşılaştırılması

\begin{tabular}{lcccccc}
\hline \multirow{2}{*}{ Sevecenlik } & & $\mathrm{n}$ & $\bar{X}$ & $\mathrm{s.s}$ & $\mathrm{t}$ & $\mathrm{p}$ \\
\hline \multirow{2}{*}{ Umursamazlık } & Anne & 188 & 17.50 & 2.93 & 1.93 & .048 \\
& Baba & 113 & 16.68 & 3.27 & & \\
\hline \multirow{2}{*}{ Paylaşımların Bilincinde Olma } & Anne & 188 & 7.88 & 3.166 & 1.546 & .123 \\
& Baba & 113 & 8.46 & 3.162 & & \\
\hline \multirow{2}{*}{ Bağlantısızlık } & Anne & 188 & 16.11 & 2.842 & -.265 & .791 \\
& Baba & 113 & 16.19 & 2.719 & & \\
\hline \multirow{2}{*}{ Bilinçli Farkındalık } & Anne & 188 & 8.64 & 3.170 & -.169 & .866 \\
& Baba & 113 & 8.58 & 3.061 & & \\
\hline \multirow{2}{*}{ ilişki Kesme } & Anne & 188 & 16.57 & 2.804 & 1.132 & .259 \\
\hline \multirow{2}{*}{ Merhamet Toplam } & Baba & 113 & 16.19 & 2.911 & & \\
\hline
\end{tabular}

Tablo 8'e göre sadece merhamet ölçeğinin "sevecenlik" alt boyutunda annelere dönük anlamlı fark söz konusudur. Diğer alt boyutlarda anlamlı düzeyde bir farklılaşmanın olmadığı bulunmuştur.

Tablo 9. Özel Gereksinimli Çocuğa Sahip Anne Babalarının Öz-Anlayış, Merhamet ve Yaşam Doyumları Arasındaki Ilişki

\begin{tabular}{lcc}
\hline & Yaşam Doyum P. & p \\
\hline Öz-anlayış & $.309^{* *}$ & .000 \\
Sevecenlik & $.127^{*}$ & .028 \\
Umursamazlık & $-.161^{* *}$ & .005 \\
Paylaşımların bilincinde olma & $-.140^{*}$ & .015 \\
Bağlantısızlık & $.123^{*}$ & .033 \\
Bilinçli farkındalık & .066 & .253 \\
İlişki kesme & $-.173^{* *}$ & .003 \\
Merhamet Toplam & $.180^{* *}$ & .002 \\
\hline
\end{tabular}


Tablo 9 incelendiğinde ailelerin öz-anlayış düzeyleri ile yaşam doyumları arasında anlamlı ilişki bulunmuştur. Anne-babaların merhamet ölçeğinden aldıkları puanlar incelendiğinde sevecenlik, umursamazlık, paylaşımların bilincinde olma, bağlantısızlık, ilişki kesme ve ölçeğin toplam puanları yaşam doyum düzeyiyle anlamlı ilişki göstermiştir. Korelasyon katsayısının yönüne bakıldığında umursamazlık, bağlantısızlık ve ilişki kesme boyutları yaşam doyumuyla ters yönlü bir ilişki göstermiştir. Merhamet ölçeğinin olumsuz boyutlarında yüksek puan alan ebeveynler düşük puanlar almışlardır. Buna karşın merhamet ölçeğinin olumlu boyutları olan sevecenlik, paylaşımların bilincinde olmada yüksek toplam puanlar alan ebeveynler ise yüksek yaşam doyumları elde etmişlerdir. Merhamet ölçeğinin bilinçli farkındalık boyutu ile yaşam doyumu arasında anlamlı bir ilişkisinin olmadığı görülmüştür.

Tablo10. Özel Gereksinimli Çocukların Anne ve Babalarının Öz-Anlayış ve Merhamet Düzeyleri Yaşam Doyumunu Yordama Gücü

\begin{tabular}{lcccccc}
\hline & $\mathrm{R}^{2}$ & $\mathrm{~F}$ & $\mathrm{P}$ & Standart $\beta$ & $\mathrm{T}$ & $\mathrm{p}$ \\
\hline Öz-anlayış & .095 & 31.54 & 0.000 & .309 & 5.616 & .000 \\
\hline Öz-anlayış & & & & .292 & 4.842 & .000 \\
Sevecenlik & & & & .012 & .143 & .887 \\
Umursamazlık & .118 & \multirow{2}{*}{5.60} & 0.000 & .036 & .476 & .634 \\
Paylaşımların bilincinde olma & & & & .077 & 1.206 & .229 \\
Bağlantısızılı & & & & -.057 & -.694 & .488 \\
Bilinçli farkındalık & & & -.110 & -1.427 & .155 \\
ilişki Kesme & & & -.149 & -1.889 & .048 \\
Bağımlı Değişken: Yaşam Doyumu & & & & & \\
\hline
\end{tabular}

Stepwise Regresyon Testiyle gerçekleştirilen analizlerde denkleme ilk sırada yaşam doyumuyla en yüksek ilişkiyi gösteren bağımsız değişken öz-anlayış puanları alınmıştır. Daha sonra regresyon analizinin ikinci aşamasında denkleme ikinci bağımsız değişken olan merhamet ölçeğinin alt ölçekleri alınmıştır.Tablo 10 incelendiğinde, özel gereksinimli çocukların anne ve babalarında öz-anlayış düzeyi yaşam doyumundaki değişkenliğin yaklaşık \%9,5'ini açıklamaktadır. Bu bulgu 0,05 manidarlık düzeyinde anlamlı bir etkiyi ifade etmektedir ( $F=31,54 ; p<0,05)$. Regresyon analizinin ikinci adımında denkleme Merhamet Ölçeği bağımsız değişkenleri alındığında yaşam doyumundaki değişim yaklaşık \%11,8'e çıkmaktadır. Bu yönüyle özel gereksinimli çocukların ailelerinde merhametle ilgili değişkenler yaşam doyumuna \%2,3’lük anlamlı bir değişime neden olmaktadırTabloya bakıldığında, merhamet ölçeğinin alt boyutları ayrıntlı olarak incelendiğinde sadece ilişki kesme boyutunun yaşam doyumunu anlamlı düzeyde ve negatif yönde etkilediği görülmüştür $(\beta=-0,149 ; p<0,05)$. Merhamet ölçeğinin diğer alt boyutları yaşam doyumunu anlamlı düzeyde yordamadığı görülmektedir.

\section{Sonuçlar}

Araşttrma örneklemine bir bütün olarak bakıldığından ebeveynlerin yüksek yaşam düzeylerine sahip olduğu görülmektedir. Bununla birlikte ilave analizlerde özel gereksinimli çocuğa sahip olan babaların yaşam doyumlarının annelerden daha yüksek düzeyde olduğu görülmüştür. Dereli ve Okur'un (2008) yaptıkları çalışmada özel gereksinimli çocuğa sahip ebeveynlerin depresyon düzeylerinin çok değişkenlik gösterdiği özellikle annelerin daha yüksek depresyon ve daha düşük yaşam doyumu sergiledikleri görülmüştür. Benzer şekilde Deniz vd., (2009) yapmış oldukları araştirmada anneler babalara kıyasla daha yüksek kaygı, endişe buna karşın daha düşük yaşama doyumu göstermektedir. Akandere vd., (2009) yapmış oldukları bir araştırmada zihinsel, fiziksel ve zihinsel-fiziksel engelli çocuğa sahip olan anne-babaların umutsuzluk ve yaşam doyum düzeyleri arasında anlamlı bir ilişki olduğunu saptamışlardır. Benzer bir araştırmada Dal (2015), duygusal zekâ düzeyi ile yaşam doyumu arasında pozitif bir ilişkinin önemine vurgu yapmaktadır. Yine bir başka çalışmada Erol (2016), utangaçlık ile yaşam doyumu arasında negatif anlamlı bir ilişki olduğunu saptamıştı. Tuncer (2017) yapmış olduğu araştırmasında sosyal anksiyete düzeylerinin yaşam doyumunu azalttğını vurgulamıştır. Bu araştrrma bulgularına göre kişinin yaşam doyumu çok fazla faktörden etkilenmektedir. İçsel ve çevresel faktör olarak iki başlık altına alınabilecek bu faktörlerin etkisinin azalması ya da artması yaşam doyumunu etkilemektedir. Annelerin, özel gereksinimli çocuğuyla geçirdiği zaman ve etkileşimlerinde ortaya çıkan problemler onların yaşam doyum ve enerjilerini olumsuz etkilemektedir. Yapılan çalışmalar ile bu araştırmada yaşam doyumuna ilişkin elde edilen bulgularla paralellik göstermektedir.

Özel gereksinimli çocuğa sahip anne ve babaların çocuklarının mevcut durumlarını anlamlandırmaları açısından kaygı ve reddetme, anlaşmazlık, suçlama, yalnızlık gibi olumsuz duygularını gösterdiğine ilişkin araştırma bulguları söz konusudur (Beckman, 1983; Ersanlı ve Kutlu, 1998; Kazak ve Marvin, 1984; Kutlu, 1998). Bu araştırmaların sonuçları 
bu çalışmanın bulgularıyla kısmen çelişmektedir. Araştırma sonuçlarından da görüldüğü gibi, gereksinimli bir çocuğa ebeveynlik etmenin sorumluluğu ve zorluğu büyüktür. Engelli çocuğa sahip anne-baba ve diğer aile bireylerinin ilişkileri giderek çevreden kopabilir, sosyal yaşamdan uzaklaşabilir, böylece duygusal destek alabilme olasılığı azalır ve toplumdan soyutlanmış hale gelebilir. Buna karşın bu araştırmada ortaya konan bulgulara göre engelli çocuğa sahip ebeveynler kendilerine yönelik kısmen öz-anlayışlıdırlar. Bu yönüyle araştırma örneklemindeki ebeveynler çocuklarının engel durumlarından kaynaklı olumsuz bir öz-anlayış yerine kendilerine özenli ve anlayışlı davranmayı, yaşadıkları olumsuz süreçlerin doğal ve bahşedilmesi gerekli bir olgu olduğu, içinde bulundukları olumsuz duygu ve düşüncelerin etkisiyle çaresizlik içerisinde bir durum göstermektense bilinçli bir şekilde hareket etme yaklaşımına sahip oldukları söylenebilir.

Bu araştırmanın bulgularına göre özel gereksinimli çocukların anne ve babalarında öz-anlayış düzeyi, yaşam doyumundaki değişkenliğin yaklaşık \%9,5'ini açıklamaktadır. Bu açıklama gücü aynı zamanda öz-anlayış ve yaşam doyumu arasında güçlü bir bağın kanıt da olabilir. Neff ve McGehee'ye göre (2010) anne-babanın destekleyici ve eleştirici tutumları ile öz-anlayışları ve dolaylı olarak da çocuğun tutumları arasında anlamlı bir ilişki söz konusudur. Öz-anlayışı olumlu ve yüksek düzeyde olan ebeveynlerin çocuklarına yönelik daha olumlu bir tutuma ve destekleyici bir role sahip oldukları görülmüştür. Bu ebeveynlerin çocuklarının da anne babalarına karşı olumlu tutumlar sergilediği gözlemlenmiştir. Bu araştırmada zihin engelli çocukların ebeveynlerinin cinsiyetlerine göre öz-anlayışlarında anlamlı bir fark görülmemiştir. Neff ve McGehee'nın (2010) gerçekleştirdikleri araştırmada, öz-anlayışın cinsiyet göre farklılaşmadığı görülmüştür. Bununla birlikte cinsiyete göre öz-anlayış düzeyinin farklılaştı̆̆ını ortaya koyan çalışmalarda mevcuttur. Raes (2010) yapmış olduğu çalışmasında kadınların erkeklerden anlamlı düzeyde düşük öz-anlayış puanlarını saptamıştır. Bunula birlikte Neff ve Vonk'un (2009) çalışmalarında öz-anlayış arasında anlamlı ve pozitif ilişkiler görülmüştür. Literatüre bakıldığında genel olarak cinsiyet öz-anlayış açısından önemli bir faktör değilken yaşla birlikte bireylerin öz-anlayışlarının arttğı görülmektedir. Bu çalışmanın sonuçları literatürdeki cinsiyet bulgularıyla tutarlılık göstermektedir.

Regresyon analizinin ikinci adımında denkleme Merhamet Ölçeği bağımsız değişkenleri alındığında yaşam doyumundaki değişim yaklaşık \%11,8'e çıkmaktadır. Bu yönüyle özel gereksinimli çocukların ailelerinde merhametle ilgili değişkenler yaşam doyumuna \%2,3’lük anlamlı bir değişime neden olmaktadır. Merhamet ölçeğinin alt boyutları ayrıntılı olarak incelendiğinde sadece ilişki kesme boyutunun yaşam doyumunu anlamlı düzeyde ve negatif yönde etkilediği görülmüştür. Bu çalışmanın sonuçları Brettle ve Grant'in (2004) sağlık çalışanları üzerinde gerçekleştirdiği araştırma sonuçlarıyla paralellik göstermektedir. Brettle ve Grant’a (2004) göre öz-anlayış ve merhamet düzeyi olumlu ve yüksek olan sağlık çalışanları daha düşük tükenmişlik düzeyi ve daha yüksek bir yaşam doyumu algısına sahiptirler. Farklı bir çaIışmada Neff $(2003$,$) öz anlayış, yaşam doyumu, sosyal bağlılık ve öznel iyi oluş algısı arasında oldukça yüksek ve anlamlı$ bir ilişki olduğunu ortaya koymuştur. Bu çalışmada öz-anlayış, merhamet ve yaşam doyumu değişkenleri arasında elde edilen sonuçlar literatürle tutarlılık göstermektedir.

Özel gereksinimli çocuğa sahip anne babalar Merhamet Ölçeğinin üç olumlu boyutundan "sevecenlik" alt ölçeğinde çok yüksek düzeyde, "paylaşımların bilincinde olma" ve "bilinçli farkındalık" alt ölçeklerinde ise yüksek düzeyde puan ortalamaları elde etmişlerdir. Buna karşın ebeveynler ölçeğin üç olumsuz boyutunda ise (umursamazlık, bağlantısızlık, ilişki kesme) düşük puanlar elde etmişlerdir. Bu açıdan ebeveynlerin olumlu merhamet özellikleri yüksek, buna karşın olumsuz olanlar ise düşük düzeyde sergiledikleri görülmektedir. Christensen ve De Blassie'ye göre (1980) özel gereksinimli çocuğa sahip birçok ailede böyle bir çocuğa sahip olmaları psikolojik açısından bir uyarılma, dayanak noktası ve anlamlandırma süreci sağlar. Bu süreçte anne ve babalar kendi aralarında ve çocuklarına karşı merhamet, sevgi, empati vb. gibi olumlu duyguları daha yüksek düzeyde gösterirler. Bu çalışmada elde edilen sonuçlar bu çalışmanın bulgularıyla paralellik göstermektedir. Bu araştırmanın önemli bulgularından biriside Merhamet Ölçeğinin sevecenlik alt boyutunda anne ve babaların puanları arasında anlamlı fark bulunmasıdır. Bu boyutta annelerin babalara kıyasla sevecenlik duygularının daha yüksek düzeyde olduğu görülmüştür. Araştırmalar özel gereksinimli çocuğa sahip ebeveynlerde etkilenme durumunun babalara kıyasla daha çok annelerde gözlemlendiği görülmüştür. Çocukla etkileşimim daha çok anneler tarafindan gerçekleştirilmesi nedeniyle bu durum annelerde stres, depresyon ve umutsuzluk gibi özelliklerin daha fazla görüldüğü gözlemlenmiştir (Scharer, 2009; Uğuz, Toros, İnanç ve Çolakkadıoğlu 2004).

Bu araştırmanın önemli bulgularından biri ailelerin öz-anlayış düzeyleri ile yaşam doyumları arasında anlamlı ve güçlü bir ilişkinin olduğunun belirlenmesidir. Olgusal olarak öz-anlayış kişinin acı ve başarısızlık durumlarında kendini eleştirmekten daha çok kendine anlayışlı davranmayı, yaşadığı olumsuz ve güçlüklerin, insan yaşamının bir parçası olarak görmeyi, negatif düşüncelerin üzerinde çokça durmak yerine olumlu bir bilinç hale getirme olarak açıklanabilir (Neff, 2003 a). Kişinin kendi acısına açık olmayı, acısını dindirme isteği üretmesi, şefkatle onu iyileştirmesi ve en önemlisi de daha büyük bir tecrübe kazanmanın bir parçası olarak kendi acı, yetersizlik ve başarısızlığını sorgulamadan anlamayı içermektedir. Kendilerine şefkat gösteren kişiler, kendisine yönelik sert bir öz-eleştiri ve sorgulamada bulunmazlar

| Kastamonu Eğitim Dergisi, 27(1), 2019| 
(Neff, 2003a; Neff, 2003b; Neff, Hsieh ve Dejitterat, 2005). Öz-anlayışı yüksek insanalarda olumsuz duygu ve düşünceler daha az görülmektedir Gilbert ve Irons, 2004). Yaşam doyumuna kavramsal olarak bakıldığı zaman da Vara'ya göre (1999), yaşam doyumu; yaşam içerisinde pozitif duygunun negatif duyguya hâkim olmasıdır. Yaşama dönük pozitif algııının artmasıdır (Ünal, 2011). Çünkü umut ve iyimser bakış olumlu yanlarımız olduğu için yaşamdaki güçlüklerin üstesinden gelebilecek yaşam enerjisini bulabiliriz. Tersinden bakıldığı zaman çabuk çöküntü, küçük olumsuzluklardan yakınma ve vazgeçme gibi yaşam senaryoları sergileyebiliriz. Nitekim Akandere vd., (2009) yapmış oldukları araştırmada umutsuzluğu, yaşam doyumunu düşüren bir neden olarak belirtmişlerdir. Bir başka çalışmada Dal (2015), duygusal zekâ düzeyi ile yaşam doyumu arasında pozitif yönlü bir ilişkinin olduğunu vurgulamaktadır. Duygusal zeka ile insanlar etrafinda olup biten gelişmeleri daha sakin ve insancıl izlerler. Sorunları ve yetersizlikleri ile başaçıkmak için daha sakin, daha bilinçli ve kendilerine daha nazik davranırlar. Öte yandan insan ilişkilerini daha sağlıklı ayarlarlar ve empatik bir tutum gösterirler. Gelişen sorunu, abartılı ve pekiştirici bir tutum, çözümüne dönük kolay değil zorlaştırıcı bir özellik taşır. Tam tersi bakış açımız ve algımızla da ilgili olduğunu, çözüm yollarının olabileceği, alınabilecek çeşitli desteklerle üstesinden gelinebileceği unutulmamalıdır. Nitekim Tuncer (2017), yapmış olduğu bir araştırmada, sosyal kaygının yaşam doyumunu olumsuz bir şekilde etkilediği ve düşürdüğünü vurgulamaktadır.

\section{5. Öneriler}

Bu araştırma, özel gereksinimli çocuğa sahip anne babaların öz-anlayışlarının ve merhametli bir tutum sergilemelerinin, yaşam doyumlarını olumlu yönde etkilediği bulgusu açısından önemlidir. Araştırma bulgularına şu öneriler geliştirilebilir:

1. Özel gereksinimliçocuğa sahip anne babalara öz-anlayışve merhamet düzeylerini artırıcı psikoeğitim programları verilebilir.

2. Bu ailelere grup rehberliği ve grupla psikolojik danışma hizmetleri sağlanarak onların bilgi gereksinimleri karşılabilir.

3. Orta ve uzun dönemli amaçlar belirlenerek merhametli ve öz-anlayışlı insan yetiştirmeye dönük değerler eğitimi programları ile zenginleştirilmiş etkinlikler yapılabilir.

4. Psikolojik danışmanlar ve psikologlar deneysel desenli grup çalışmaları yaparak öz-anlayış kazanma ve merhametli tutum kazanma gibi eğitim programları sınayarak anne babalara olumlu bakışlar kazandırabilirler.

\section{Kaynakça}

Akandere, M., ve Acar, M. (2009) Zihinsel ve fiziksel engelli çocuğa sahip anne ve babaların yaşam doyumu ve umutsuzluk düzeylerinin incelenmesi. Selçuk Üniversitesi Sosyal Bilimler Dergisi, (22), 17-32.

Akdeniz, S., \& Deniz, M. E. (2016). The turkish adaptation of compassion scale: The validity and reliability study. The Journal of Happiness Well-Being, 4 (1), 50-61.

Avşaroğlu, S. (2012). Zihinsel yetersizliğe sahip çocuğu olan anne-babaların kaygı düzeylerinin incelenmesi. Uluslararası Insan Bilimleri Dergisi, 9 (1), 533-549.

Avşaroğlu, S., Deniz, M. E., ve Kahraman, A. (2005). Teknik öğretmenlerde yaşam doyumu, iş doyumu ve mesleki tükenmişliğin incelenmesi. Selçuk Üniversitesi Sosyal Bilimler Enstitüsü Dergisi, 14, 115-129.

Avşaroğlu, S., ve Gilik, A. (2017). Özel gereksinimli çocuğa sahip anne babaların kaygı durumlarına göre umutsuzluk düzeylerinin incelenmesi. Ilköğretim Online, 16(3), 1022-1035.

Bandura, A. (1997). Self-efficacy: The Exercise of Control. New York: Freeman.

Baykoç, D. N., Bayhan, P., ve Artan, i. (2000). Engelli çocuğa sahip ailelerin beklentileri ve endişe duydukları konuların incelenmesi. Sosyal Hizmetler Dergis, 1 (11), 16-23.

Beckman, P. J. (1983). Influence of selected child characteristic on stress in families of handicapped infants. American Journal of Mental Deficiency, 88 (2), 150-156.

Braun, J. M. (1992). Compassion and the psycho therapist. (Unpublished Phd Thesis). California, CA: California Institute Of Integral Studies.

Brettle, A., \& Grant, M. J. (2004). Finding the evidence for practice: A Work Book For Health Professionals. London: Churchill Livingstone.

Cassell, E. J. (2002). Compassion.in C. R. snyder and shane J. Lopez (Ed.), Handbook of Positive Psychology, New York: Oxford University, $434-445$.

Cavkaytar, A. (2010). Özel eğitime gereksinim duyan çocuklar ve özel eğitim. H. Diken (Ed.), Özel Eğitime Gereksinimi Olan Öğrenciler ve Özel Eğitim. Ankara: Pegem.

Deniz, M. E. Sahin, K. \& Sümer, S. A. (2008). The validity and reliability of the turkish version of the self-compassion scale. Socıal Behavıor and Personality, 36 (9), 1151-1160.

Deniz, M. E., ve Yılmaz, E. (2006). Üniversite öğrencilerinin duygusal zekâ ve stresle başaçıkma stilleri arasındaki ilişkinin incelenmesi. Türk Psikolojik Danışma ve Rehberlik Dergisi, 3 (25), 17-26.

Dereli, F., ve Okur, S. (2008). Engelli çocuğa sahip ailelerin depresyon durumunun belirlenmesi. Yeni Tıp Dergisi, 25, 164-168. 
Diener, E., Emmons, R., Larsen, R. J., \& Griffin, S. (1985). The satisfaction with life scale. Journal Of Personality Assessment, 49, 71-75.

Diener, E., \& Diener, C. (1996). Most people are happy. Psychological Science, 7, 181-185.

Eripek, S. (2009) Zihinsel Yetersizliği Olan Çocuklar, Ankara: Maya Akademi.

Ersanlı, K., ve Kutlu, M. (1998). Zihinsel engelli çocuğu olan annelerin umutsuzluk düzeyleri. 7. Konya: Eğitim Bilimleri Kongresi.

Gilbert, P. (2005). Compassion and cruelty: A biopsychosocial approach. I. P., Gilbert (Ed.), Compassion: Conceptualisations, Research and Use In Psychotherapy, London: Routledge, 9-74.

Gilbert, P. (2009). The compassionate mind: A New Approach To Life's Challenges. New Harbinger

Gowen, J. W., Martin, J. N., Goldman, B. D., \& Appelbaum, M. (1989). Feelings of depression and parenting competence of mothers of handicapped and non handicapped infants: A longitudinal study. American Journal on Mental Retardation. 94 (3), $259-271$.

Güleş, E., ve Avşaroğlu, S. (2017). Özel gereksinimli çocuğu olan anne babaların merhamet düzeyleri. Alanya: II. Ines uluslararası akademik araştrmalar kongresi. 18-21 Ekim.

Heller, T., Hsieh, K., \& Rowitz, L. (1997). Maternal and paternal caregiving of persons with mental retardation across the lifespan. Family Relations, 46 (4), 407-415.

Hergül, B. (2010). Dünya Tek Kişilik Değil. acikarsiv.atilim.edu.tr.

Hökekli, H. (2007). Bir değer "merhamet". Dem Dergisi, 1 (4), 78-82.

Karasar, N. (1994). Bilimsel Araştırma Metodu. Ankara: Hacettepe Taş Kitapçılık.

Karatekin, H. (2013). Benlik yapılarına göre başa çıkma stratejileri ve yaşam doyumunun incelenmesi. (Yayımlanmamış yüksek lisans tezi). Ankara: Gazi Üniversitesi Eğitim Bilimleri Enstitüsü.

Kazak, A. E., \& R. Marvin. (1984). Differences, difficulties and adaptation: stress and social networks in families with handicapped child. Family Relations, 33, 67-77.

Knafl, K., \& Zoeller, L. (2000). Childhood chronic illness: A comparison of mothers' and fathers' experiences. Journal of Family Nursing, 6(3), 287-302.

Köker, S. (1991). Normal ve sorunlu ergenlerin yaşam doyumu düzeylerinin karşılaştırılması. (Yayımlanmamış yüksek lisans tezi). Ankara: Ankara Üniversitesi Sosyal Bilimler Enstitüsü.

Krauss, M. W. (1993). Child-related and parenting stres: similarities and differences between mothers and fathers of children with disabilities. American Journal on Mental Retardation, 97(4), 393-404.

Marcenko, M. O., \& Meyers, J. C. (1991). Mothers of children with developmental disabilities: who Shares the burden? Family Relations, (40), 186-190.

Mutluer, S. Y. (1997). Tekerlekli sandalye kullanan bedensel özürlüler için uygun konut tasarımı ve çevre düzenlemesi. (Yayınlanmamış yüksek lisans tezi). Konya: Selçuk Üniversitesi Fen Bilimleri Enstitüsü.

Neff, K. D. (2003). Self-compassion: An alternative conceptualization of a health attitude to ward. Self and Identity, 2(2), 85-101.

Neff, K. D. (2003). The development and validation of a scale to measure self-compassion. Self and Identity, 2, 223-250.

Neff, K. D., \& McGhee, P. (2010). Self-compassion and psychologycal resilience among adolescents and young adults. Self and Identity, 9, 225-240.

Neff, K. D., Hsieh, Y., \& Dejitterat, K. (2005). Self-compassion, achievement goals, and coping with academic failure. Self and Identity, 4 (3), $263-287$.

Özşenol, F., Işıkhan, V., Ünay, B., Aydın, H. İ., Akın, R., ve Gökçay, E. (2003). Engelli çocuğa sahip ailelerin işlevlerinin değerlendirilmesi. Gülhane Tıp Dergisi, 45 (2), 156-164.

Pommier, E. A. (2011). The compassion scale dissertation abstracts international section. Humanities and Social Sciences, 72, $1167-1174$.

Raes, F. (2010). Rumination and worry as mediators of there lation ship between self-compassion and depression and anxiety. Personality and Individual Differences, 48, 757-761.

Sarıcaoğlu, H. (2015) Bilinçli öz-anlayış programının üniversite öğrencilerinin öz-anlayış düzeylerine etkisi. (Yayınlanmamış Doktora Tezi). Konya: N.E.Ü Eğitim Bilimleri Enstitüsü.

Sayar, K. (2011). Merhamet: kalbe dönüş için son çağrı, İstanbul: Timaş Yayınları.

Scharer, K. (2009). A comparison of two types of social support form theirs of mentally children. JCAPN, 22, 86-98.

Schopenhauer, A. (2007). Merhamet, (çev. Zekai Kocatürk). İstanbul: Dergâh Yayınları.

Selçukoğlu, Z. (2001). Araştırma görevlilerinde tükenmişlik düzeyi ile yalnızlık düzeyi ve yaşam doyumu arasındaki ilişkinin bazı değiş̧kenler açısından değerlendirilmesi. (Yayımlanmamış yüksek lisans tezi). Konya: Selçuk Üniversitesi Sosyal Bilimler Enstitüsü.

Seligman, M., Steen, T., Park, N., \& Peterson, C. (2005). Positive psychology progress: Empirical validation of interventions. American Psychologist, 60 (5), 410-421.

Tuncer, N. (2017). Bir grup üniversite öğrencisinin sosyal anksiyete düzeylerine göre bilinçli farkındalık ve yaşam doyumu. (Yayınlanmamış Yüksek Lisans tezi). İstanbul: Işık Üniversitesi Sosyal Bilimler Enstitüsü.

Tuzgöl, M. (2007). Üniversite öğrencilerinin yaşam doyumunun bazı değişkenlere göre incelenmesi. Pamukkale Üniversitesi Eğitim Fakültesi Dergisi, 2 (22),132-143.

Tümkaya, S., Hamarta, E., Deniz, M. E., Çelik, M., ve Aybek, B. (2008). Duygusal zekâ mizah tarzı ve yaşam doyumu: Üniversite öğretim elemanları üzerine bir araştırma. Türk Psikolojik Danışma ve Rehberlik Dergisi, 3 (30), 1-18.

Uğuz, Ş., Toros, F., İnanç, B. Y., ve Çolakkadıoğlu, O. (2004). Zihinsel ve bedensel engelli çocukların annelerinin anksiyete, depresyonlarının belirlenmesi. Klinik Psikiyatri, 7, 42-47.

Underwood, L. G. (2002). The human experience of Compassionate Love. In Stephen.

Vara, S. (1999). Yoğun bakım hemşirelerinde iş doyumu ve genel yaşam doyumu arasındaki ilişkinin incelenmesi. (Yayımlanmamış yüksek lisans tezi). İzmir: Ege Üniversitesi Sağlık Bilimleri Enstitüsü. 